\title{
SIX-SIGMA FOR QUALITY AND PRODUCTIVITY IMPROVEMENT OF PHARMACEUTICALS MANUFACTURING INDUSTRIES
}

\author{
Shemelis Nesibu Wodajeneh, \\ Department of Industrial Engineering, Wollo University, \\ Kombolcha Institute of Technology, Ethiopia \\ Ewnetim Seleshi, \\ Department of Industrial Engineering Wollo University, \\ Kombolcha Institute of Technology, Ethiopia
}

\begin{abstract}
The purpose of this article is to share the investigations we have done in six-sigma applications in improving the quality and productivity of manufacturing industries particularly in pharmaceutical manufacturing industries. The relationship between six-sigma and the ISO certification and the quality cost concepts are deeply discussed in this research for the tablet manufacturing section. Quality cost is analyzed based on the six sigma metrics and Taguchi loss function using 1430 sample size of tests before and after the company's certification of ISO 9000 Quality Management System.
\end{abstract}

Uses and application of Six-Sigma in the developing countries, particularly, in the African context is found to be limited or none in the recent literature review while the competitiveness of Pharmaceutical industries is challenged because of quality and productivity. The results obtained from the study revealed that the application of Six-Sigma in the company has proved quality improvement by minimizing the variations in the process.

Key Words: Six Sigma, Productivity,

\section{SIX-SIGMA METRICS CALCULATION}

Various metrics are used in six-sigma. These include the concept of 'defect opportunities' and the use of 'sigma' to measure process performance. From the collected data, there is a total sample size of 1430 which is collected from five different types of tablets. One batch of all types of tablets has ten different tests at which the tablet faces the opportunity to be a defect or not. To be specific and have a clear result this study wants to take a measure for each tablet production process individually in the case of sixsigma metrics calculation.

So that according to the data collected for paracetamol $500 \mathrm{mg}$ tablet and the pharmacopeia guideline specifications, at which EPHARM considers its production limits, the total numbers of defects from 300 sample size are 38. These samples are out of their own specific upper or lower control limits stated in the production system guideline of Epharm and pharmacopeia. Due to one or more defects in the tablet, it will send to further processing of rework. So that using the total sample size collected for paracetamol, defects in the collected samples and the appropriate formula for the sixsigma metrics, the metrics will be calculated as follows:

1. Defects per Million Opportunity (DPMO): the formula used to calculate the total number of defects in a million opportunity of tablet tests is as shown below:

$\mathrm{DPMO}=($ Total Defects/ Total Opportunities) * 1000,000

$\mathrm{DPMO}=(38 / 300) * 10^{6}$

DPMO $=\underline{126,666.7}=126,667$ defects

2. DEFECTS PER UNIT: DPU $=$ Total Defects/Total Opportunities

DPU $=38 / 300$

$\mathrm{DPU}=\underline{\mathbf{0 . 1 2 6 7}}$ 
3. $\quad$ Yield $=\mathrm{e}^{-\mathrm{DPU}}$

$$
=\mathrm{e}^{-0.1267}=\underline{\mathbf{8 7 . 3 3 \%}}
$$

Or in other way, Defects $(\%)=$ DPU *

$100 \%=12.67 \%$

Yield $=100-$ Defects $(\%)$

$=100-12.67$

$=\underline{\mathbf{8 7 . 3 3 \%}}$

\section{Sigma Level}

Using a six-sigma calculator the number of DPMO can be converted to a 'sigma level'. So that when we consider DPMO of 126,667 the sigma level for the paracetamol production section is calculated as $\mathbf{2 . 6 4 2}$.

When we consider these six-sigma metrics we have to examine it from the perspective of the type of product, pharmaceuticals, EPHARM produces. These values may be acceptable to follow if the company is plastic manufacturing or leather processing industry. But, it produces pharmaceutical products which will be taken through the human's blood. So that, the company has to reduce its process variations to produce its products in a consistence environment and improve its production system sigma level near to six-sigma so that the yield will increase to more than 99\% and DPMO will reduce to 3.4. This may not be easy to fulfill and it could also be a long term plan for the company.

\section{COST ANALYSIS USING SIX- SIGMA METRICS}

This analysis will help the researcher and EPHARM to see the current productivity stage in the case of yield and amount of money EPHARM is incurring for producing tablets with defects. In addition, it gives statistical evidence about the increase in productivity and associated cost minimization which motivates the company to move towards its higher level of sigma production.

\begin{tabular}{|c|c|c|c|c|c|}
\hline \multirow[b]{2}{*}{ Parameters } & \multicolumn{5}{|l|}{ Sigma level } \\
\hline & $\begin{array}{l}2.642- \\
\text { sigma }\end{array}$ & 3-sigma & 4-sigma & 5-sigma & $\begin{array}{l}6- \\
\text { sigma }\end{array}$ \\
\hline $\begin{array}{l}\text { Defects } \\
\text { Million }\end{array}$ & 126,667 & 67,457 & 6,297 & 236 & 3.4 \\
\hline Yield & $87.33 \%$ & $93.25 \%$ & $99.37 \%$ & $99.98 \%$ & $99.99 \%$ \\
\hline $\begin{array}{l}\text { Defect } \\
\text { Cost/year (birr) }\end{array}$ & $258,072.61$ & $137,437.5$ & $12,829.5$ & 480.83 & 6.93 \\
\hline
\end{tabular}

Table 1: Sigma level and defect cost comparison

The above table shows the comparison between different sigma level production processes and their associated cost related to the defect product in the production section. The number of defects per million opportunity, and yield are calculated using their associated formulas and then the cost associated with these defects is calculated using the production cost of paracetamol per pieces which is 0.10315 birr and annual production capacity of paracetamol which is79, 000,000 tablets. But, these tablets with defect are going to be re-processed and added to the production in the next batch.

According to the result from an interview with concerned bodies about the raw material cost $75 \%$ of the production cost is contributed from the raw material. Therefore: the defect cost is considered to be $25 \%$ of the production cost. That is: 0.02579 birr/piece.

The table tries to illustrate the current situation of EPHARM's production status in a sigma level and its cost associated with defects for only the paracetamol product. It uses the following formula to calculate these values.

\section{Current EPHARM's sigma level (2.642)}

Production cost $=0.02579 \mathrm{birr} /$ tablet

Annual production $=79,000,000$ tablets $\mathrm{DPMO}=126,667$

Defect cost per year $=($ Production cost $/$ tablet $) *$ Total defects in production

But;

Total defects $=\left[(\right.$ DPMO $*$ Annual production $\left.) / 10^{6}\right]$

Defect cost $=(0.02579 \mathrm{birr} /$ tablet $) *[(126,667 *$ $79,000,000)] / 10^{6}$

\section{$=258,072.61 \mathrm{ETB} /$ year}

As shown above in the calculation, EPHARM loses258, 072.61 ETB in a year by producing paracetamol tablet products with a current sigma level production of 2.642. Similarly, the cost that EPHARM will lose in producing tablets with defects for $3,4,5$, and 6-sigma production levels are calculated using the above procedures as shown in the table. It is clear that EPHARM can reduce its process variations and goes up towards the higher sigma level production systems. So that, if EPHARM can minimize the maximum number of tablets with defects in its production section to 6,297 and goes to a 4-sigma level production system it will lose only $12,829.57 \mathrm{ETB}$. The saving is a huge amount of money to EPHARM which increases its competitive advantage. Time to time with reducing the number of defective items in the production section EPHARM 
can get an advantage of minimizing this lose to $480.83 \mathrm{ETB}$ and $6.93 \mathrm{ETB}$ in producing the products under 5-sigma and 6-sigma production level respectively. But, one thing that everyone should have to know is that this production level advancement is not that much easy and the company should work hard to come to this stage. Considering the same procedure as used for paracetamol tablet, the six-sigma metrics for the other four tablets is calculated and summarized in the following table.

\begin{tabular}{|c|c|c|c|c|c|c|}
\hline & $\begin{array}{l}\text { Defe } \\
\text { cts }\end{array}$ & $\begin{array}{l}\text { DP } \\
\text { MO }\end{array}$ & $\begin{array}{l}\text { DP } \\
\mathbf{U}\end{array}$ & $\begin{array}{l}\text { Yiel } \\
\text { d } \\
(\%) \\
\end{array}$ & $\begin{array}{l}\text { Sig } \\
\text { ma } \\
\text { Lev } \\
\text { el } \\
\end{array}$ & $\begin{array}{l}\text { Defect } \\
\text { cost } \\
\text { Per } \\
\text { year }\end{array}$ \\
\hline $\begin{array}{l}\text { Paraceta } \\
\text { mol }\end{array}$ & 38 & $\begin{array}{l}126, \\
667\end{array}$ & $\begin{array}{l}0.1 \\
26 \\
7\end{array}$ & $\begin{array}{l}87.3 \\
3\end{array}$ & $\begin{array}{l}2.64 \\
2\end{array}$ & $\begin{array}{l}258,072 \\
.61\end{array}$ \\
\hline $\begin{array}{l}\text { Co- } \\
\text { trimoxax } \\
\text { ole }\end{array}$ & 42 & $\begin{array}{l}140, \\
000\end{array}$ & $\begin{array}{l}0.1 \\
40 \\
0 \\
\end{array}$ & 86 & $\begin{array}{l}2.58 \\
0 \\
\end{array}$ & $\begin{array}{l}273,875 \\
.00\end{array}$ \\
\hline $\begin{array}{l}\text { Theophe } \\
\text { drine }\end{array}$ & 44 & $\begin{array}{l}146, \\
667\end{array}$ & $\begin{array}{l}0.1 \\
46 \\
7 \\
\end{array}$ & $\begin{array}{l}85.3 \\
3 \\
\end{array}$ & $\begin{array}{l}2.55 \\
1 \\
\end{array}$ & $\begin{array}{l}153,476 \\
.75\end{array}$ \\
\hline $\begin{array}{l}\text { Chloroqu } \\
\text { ine }\end{array}$ & 40 & $\begin{array}{l}133, \\
334\end{array}$ & $\begin{array}{l}0.1 \\
33 \\
3 \\
\end{array}$ & $\begin{array}{l}86.6 \\
7\end{array}$ & $\begin{array}{l}2.61 \\
1\end{array}$ & $\begin{array}{l}234,667 \\
.84\end{array}$ \\
\hline $\begin{array}{l}\text { Furosami } \\
\text { de }\end{array}$ & 58 & $\begin{array}{l}193, \\
334\end{array}$ & $\begin{array}{l}0.1 \\
93 \\
3 \\
\end{array}$ & $\begin{array}{l}80.6 \\
7 \\
\end{array}$ & $\begin{array}{l}2.36 \\
6 \\
\end{array}$ & $\begin{array}{l}226,452 \\
.12\end{array}$ \\
\hline Total & 222 & & & & & $\begin{array}{l}1,146,5 \\
44.32 \\
\end{array}$ \\
\hline
\end{tabular}

Table 2: Sigma level metrics for sample tablets

As shown in table 16, likewise the paracetamol, the yield and the sigma level are not good enough to produce tablet with a minimum defect level that maximizes the productivity of the company. The defect cost for each type of tablet is calculated using its associated cost of production. The defect cost of one piece of tablet production for paracetamol, cotrimoxaxole, theophedrine, chloroquine, and furosamide is $0.02579,0.039125,0.02378,0.055$, and 0.04505 birr respectively. The above table shows that the company, EPHARM, loses a total defect loss of $1,146,544.32$ birr per year only through these five tablets. Improving the production process of the tablet section then will result with saving of a huge investment. As EPHARM is one of an ISO certified company in the pharmaceutical sector this production level of sigma level has to be improved which will result with a consistent production of quality tablets.

\section{TAGUCHI'S LOSS FUNCTION ANALYSIS}

According to Taguchi's loss function there is a loss even if the product is produced within the specification limits. Therefore, producing products within a given specification limit should not be the goal of every company. However, Taguchi realized that in much industrial production, there is a need to produce an outcome on target.

In the analysis part the control charts shows that that EPHARM's tablet production process for the selected five tablets has batch productions which are out of the upper or lower control limits. So that, as EPHARMis one of the ISO certified company in the country it should work hard to have a consistence production process and produce its products to a target or at least approaching the target value as per the Taguchi's principle. As Taguchi said the value beyond the target value is a loss to the society, thus, companies should minimize these loses by producing their products having a parameter approaching the target value.

The Taguchi's quality loss function is:

$$
\mathrm{L}(\mathrm{y})=\mathrm{k}(\mathrm{y}-\mathrm{m})^{2}
$$

Where; $\mathrm{L}(\mathrm{y})=$ failure cost of a product, $\mathrm{y}=$ actual value of the performance, $\mathrm{m}=$ target value, $\mathrm{k}=$ proportionality constant.

And the average quality loss for a product of the company is calculated using a formula;

$$
\mathrm{L}=\mathrm{k}\left(\mathrm{S}^{2}+(\mu-\mathrm{m})^{2}\right)
$$

Where; $\mathrm{S}$ the mean square deviation of $\mathrm{y}$ around its own mean and $\mu$ is the average value of $y$ for the set of parts.

\section{Quality loss calculation}

Quality loss of paracetamol is calculated using the principle of Taguchi's loss function. The value of $\mathrm{L}$ (failure cost) used in this formula is taken by considering the production cost $\mathrm{PC}=0.10315 \mathrm{birr} /$ piece of paracetamol and the reprocessing of tablets when they face defects. The following points are assumptions considered in calculating quality loss at EPHARM.

- $\quad$ Failure cost for a product was considered as the production cost since the tablets with such Taguchi quality loss are not going to be re-processed because they are produced 


\section{International Journal of Engineering Applied Sciences and Technology, 2019 \\ Vol. 4, Issue 4, ISSN No. 2455-2143, Pages 218-225 \\ Published Online August 2019 in IJEAST (http://www.ijeast.com)}

between the specification limits and are accepted by the guideline.

- Maximum loss is at the tolerance limits (upper tolerance limit and lower tolerance limit)

- One performance parameter of a product was considered in the calculation because the above formula developed by Taguchi does not perform loss calculation for many parameters simultaneously.

Note that: $\mathrm{S}=$ Standard deviation, $\mu=$ mean value of samples, $\mathrm{m}=$ target value, $\mathrm{TL}=$ tolerance limit, $\mathrm{L}=$ failure cost of the product.

Quality loss is calculated for the deviation of assay of the product from its target value.

$\mathrm{S}=2.06, \mu=99.21 \%, \mathrm{~m}=100 \%, \mathrm{TL}=100 \pm 5 \%$ and $\mathrm{L}=0.10315$ birr

Given the values above, the failure cost of paracetamol per piece can be calculated as shown below:

$$
\begin{aligned}
& \mathrm{L}(\mathrm{y})=\mathrm{k}(\mathrm{y}-\mathrm{m})^{2} \\
& 0.10315=\mathrm{k}(95-100)^{2} \\
& \mathbf{k}=\mathbf{0 . 0 0 4 1 2 6}
\end{aligned}
$$

Therefore, the average quality loss is,

$\mathrm{L}=\mathrm{k}\left[\mathrm{S}^{2}+(\mu-\mathrm{m})^{2}\right]$

$\mathrm{L}=0.004126\left[(2.06)^{2}+(99.21-100)^{2}\right]$

$\underline{\mathbf{L}=0.02008 \text { birr/tablet }}$

This is the average quality loss for only one type of product namely paracetamol $500 \mathrm{mg}$ with a loss to the society of 0.02008 ETB per one tablet. Annual quality loss for this product can also be determined by using the annual production of the paracetamol in the following way:

- $\quad$ Average quality loss $=0.02008 \mathrm{birr} / \mathrm{piece}$

- Batch size for paracetamol $=200,000$ tablets

- Annual production of paracetamol = $79,000,000$ tablets

Using this data:

Annual average quality loss $=($ Annual production $) *$ Average quality loss

$$
=79,000,000 \text { tablets } * 0.02008 \text { birr/tablet }
$$

\section{$=1,586,320 \mathrm{ETB} /$ year}

Therefore: the annual average societal quality loss for paracetamol $500 \mathrm{mg}$ is calculated as $\mathbf{1 , 5 8 6 , 3 2 0}$ ETB. According to the concept this loss may come from the company itself or the customers/patients who will pay for the tablet.
Similar to the paracetamol tablet, the annual quality loss for the other four types of tablets is calculated and summarized in the table below.

\begin{tabular}{|l|l|l|}
\hline S.No & Tablet Name & $\begin{array}{l}\text { Annual Quality } \\
\text { Loss (birr) }\end{array}$ \\
\hline 1 & Paracetamol & $1,586,320.00$ \\
\hline 2 & $\begin{array}{l}\text { Co- } \\
\text { trimoxaxole }\end{array}$ & $2,189,018.60$ \\
\hline 3 & Theophedrine & $1,244,882.66$ \\
\hline 4 & Chloroquine & $1,582,097.36$ \\
\hline 5 & Furosamide & $1,740,793.36$ \\
\hline & Sum & $\mathbf{8 , 3 4 3 , 1 1 1 . 9 8}$ \\
\hline
\end{tabular}

Table 3: Sample tablets annual quality loss after ISO certification

It is shown that the total societal loss due to the production of tablet out of the target value is around $8,343,111.98$ birr in one year. This loss tells us that the tablet production system of EPHARM is not consistent to produce the tablets near to their target value of parameter value. The values may be are between the specification limits but far from the required target value. This type of quality loss is not considered at EPHARM. It will come either from the company itself or the end customer who pay for the tablet.

In general, if the production is above the target value the company may incur additional cost of raw material because of its misuse of raw material proportion per tablet and if the production is below the target value the patient cannot get the exact amount of drug content which cures him/her in a minimum possible time. Due to this the patient may need additional time on bed which results with reduction of productive labor force for the society or he/she costs additional money for another tablet.

To identify the contribution of each variables in the quality loss cost calculated above the following analysis is done. The Assay (Drug content of a tablet) is the final variable test conducted in the company which can show the effect of other variables in a cumulative way. But, each variable has its own effect in this loss of quality cost in manufacturing the tablets far from the required target value of assay composition. 


\begin{tabular}{|c|c|c|c|c|c|c|c|c|c|}
\hline \multirow[b]{2}{*}{$\begin{array}{l}\text { S. } \\
\mathbf{N}\end{array}$} & \multirow[b]{2}{*}{$\begin{array}{l}\text { Varia } \\
\text { ble } \\
\text { Name }\end{array}$} & \multicolumn{5}{|c|}{ Number of Defects } & \multirow[b]{2}{*}{$\begin{array}{l}\text { To } \\
\text { tal } \\
\text { de } \\
\text { fec } \\
\text { ts }\end{array}$} & \multirow[b]{2}{*}{$\begin{array}{l}\% \text { of } \\
\text { Defe } \\
\text { cts }\end{array}$} & \multirow[b]{2}{*}{$\begin{array}{l}\text { Cost } \\
\text { (Birr) }\end{array}$} \\
\hline & & 1 & 2 & 3 & 4 & 5 & & & \\
\hline 1 & $\begin{array}{l}\text { Weig } \\
\mathrm{ht}\end{array}$ & 0 & 0 & 0 & 0 & 1 & 1 & 0.46 & $\begin{array}{l}38,378 \\
.32\end{array}$ \\
\hline 2 & $\begin{array}{l}\text { Diam } \\
\text { eter }\end{array}$ & 3 & 4 & 0 & 3 & $\begin{array}{l}2 \\
0\end{array}$ & 30 & $\begin{array}{l}13.6 \\
9\end{array}$ & $\begin{array}{l}1,142, \\
172.02\end{array}$ \\
\hline 3 & $\begin{array}{l}\text { Hardn } \\
\text { ess }\end{array}$ & $\begin{array}{l}1 \\
4\end{array}$ & $\begin{array}{l}1 \\
7\end{array}$ & $\begin{array}{l}1 \\
4\end{array}$ & 7 & $\begin{array}{l}1 \\
1\end{array}$ & 63 & $\begin{array}{l}28.7 \\
7\end{array}$ & $\begin{array}{l}2,400, \\
313.32\end{array}$ \\
\hline 4 & $\begin{array}{l}\text { Thick } \\
\text { ness }\end{array}$ & $\begin{array}{l}2 \\
0\end{array}$ & $\begin{array}{l}1 \\
9\end{array}$ & $\begin{array}{l}3 \\
0\end{array}$ & $\begin{array}{l}3 \\
0\end{array}$ & $\begin{array}{l}2 \\
6\end{array}$ & $\begin{array}{l}12 \\
5\end{array}$ & $\begin{array}{l}57.0 \\
8\end{array}$ & $\begin{array}{l}4,762, \\
248.32\end{array}$ \\
\hline 5 & Assay & 0 & 0 & 0 & 0 & 0 & 0 & 0 & 0 \\
\hline & & & & & & & $\begin{array}{l}\text { Tot } \\
\text { (Bir }\end{array}$ & & $\begin{array}{l}8,343, \\
111.98\end{array}$ \\
\hline
\end{tabular}

Table 4: Defect and Cost contribution of individual variables

Where: 1- Paracetamol, 2- Co-trimoxaxole, 3- The ophedrine, 4- Chloroquine, 5- Furosamide

Table 18 presents the defect contribution of the variables in the collected data. For, example the thickness of the tablet contributes $20,19,30,30$, and 26 defects in Paracetamol, Co-trimoxaxole, Theophedrine, Chloroquine, and Furosamide tablets respectively. Therefore: thickness contributes $57.08 \%$ of the defects in the tablets production section which results with out of target production of tablets in assay.

To see this individual effect of variables, the total calculated quality loss cost, i.e. 8,343,111.98, will be considered. As shown in the table, all the effects come from the other variables not from the addition of drug content process itself.

The thickness of the tablet defects contributes more than $50 \%$ of the problems and also the loss in the Taguchi quality cost. The tablet hardness and Diameter are the second and third variables which contribute 2,400,313.32 Birr loss and 1,142,172.02 Birr loss respectively. From the pharmacopeia guideline, the GMP for the pharmaceutical production and information from EPHARM these three variables are considered as in-house variables which are not asked to be fulfilled in the international guidelines but considered only at the company level. Even if these variables are not asked by the guidelines, they can highly determine the in/out of process of the tablet because they are the immediate causes for the other variables during production. Considering this, the production limits of these variables are may be enough to produce tablets in the control limits of assay but they are not good enough to produce near to the target value. So that in order to improve the production process, the company should give more emphasis on thickness and then based on their priority order of cost contribution to the Taguchi quality loss.

\section{SIX-SIGMA AND ISO}

An Overview of ISO 9000-ISO 9000 is a wellestablished international standard for quality management systems for all kinds of companies in nearly every industry. Developed by Technical Committee 176 of the International Organization for Standardization (ISO), it has evolved - based on input from companies and institutions - from a theoretical set of requirements in 1987 to a practical and process-oriented approach to assess the framework for quality management in 2000 .

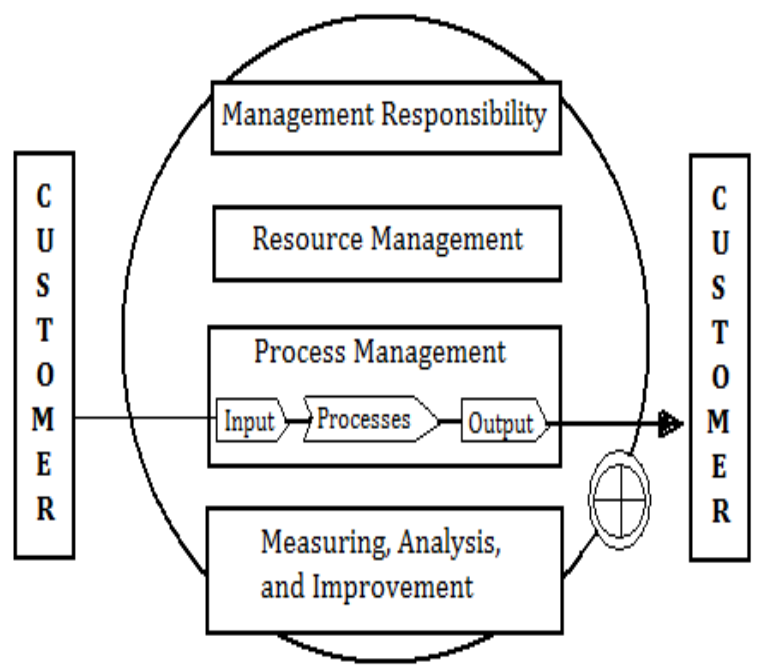

Figure 1 Process Model of ISO 9000:2000 (source: Zhang, Z. 2000)

In the early stage of ISO 9000 , there was no focus on continuous improvement apart from quality management system elements such as "control of non-conforming products" and "corrective and preventive actions."

\section{Combining Six-Sigma with ISO Requirements}

Businesses that want to improve overall quality are often faced with the difficult task of selecting the most effective quality improvement technique from available options such as Six Sigma and ISO 9000. For selecting the most suitable technique, businesses will have to look at the merits of each of these 
techniques and determine their applicability in the context of existing business processes. This is necessary because there is a difference in the concepts of both the approaches, which need to be identified before selecting any one of the approaches. One of the major differences between both systems is that ISO 9000 is a shell of requirements without any tools, whereas Six Sigma is a methodology connecting tools and procedures for applying these tools through a systematic manner.

But both of these two methodologies which improve the quality management system and process can also be highly complementary. Unfortunately, the two concepts often are undertaken by different project leaders and teams which compete for resources and therefore resulted with not as such that expected. But there is, however, a way to combine the power of the two methodologies to add a significant value to the company. It is a waste to have a quality management system and process improvement approach existing side-by-side without any integration. Aligning ISO 9000 and six-sigma can help to improve the credibility of the ISO 9000 quality management system and the sustainability of the six sigma initiatives at the same time. It can save resources and investments and also it enriches the way to manage the business.

This study tries to come up with a solution to these two problems of the two methodologies. This is just summarized as the following figure at which the overall ISO model is revised and improved in its continuous improvement part. As shown in the above model, the continuous improvement is done only through Measuring, Analyzing, and Improving manner but the method and tools used to perform these activities are not clearly stated and guide the company to facilitate process improvement in EPHARM. The ISO methodology doesn't show that which tools can be used for measuring, analyzing or improving the processes. Since the new model shown below uses Six Sigma as its continuous improvement tool it can go further through the detail improvement process with the advantage of two additional procedures called Define and Control which enable any concerned body in the company to know more about the processes and control the specification limits. Added to this, the new model can guide the company/Project team to select which tool to perform any activity and make the work easy. Therefore an ISO and Six Sigma can be used in this new and improved model by supporting and give a solution for one another.

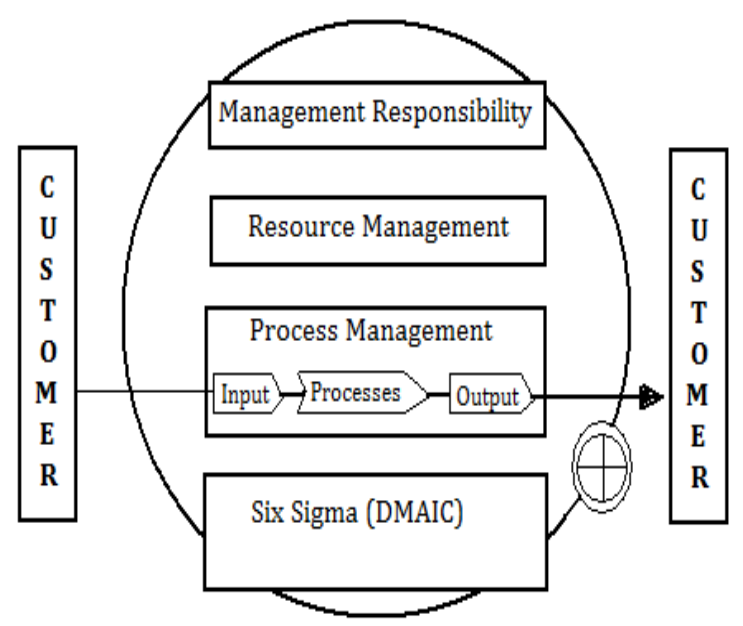

Figure 2 Improved Process Model of ISO 9000:2000

Therefore for every requirement points in the certification process that need a measurement tool, because ISO doesn't give a way how to perform the measurement, Six-sigma can be a solution to select the tool and fulfill the requirement of the ISO certification. Through this EPHARM can give a specific solution for a specific problem by analyzing it using the correct tool.

Even if the company is currently certified with ISO 9000 , the certification by itself cannot be a guarantee to know how to tackle the problems during production to maximize the performance of productivity and quality. So that the company has to apply an appropriate tool to address the requirements of ISO.

Looking at the new ISO 9000:2000 requirements and comparing these requirements with the Six Sigma gap-analysis shows the possibility of connecting both approaches and systems with each other. Six-sigma needs to be added after a certain time frame in order to keep the improvement and in order to help Six Sigma get into the company's bloodstream. ISO 9000 is designed to assess companies based on both external and internal requirements and to help close the gaps on a mid-term and long-term basis. By adding typical Six Sigma requirements to the ISO 9000:2000 internal audit questionnaires, a company can make Six Sigma part of its quality management system and improve the effectiveness and efficiency of the Six Sigma initiative significantly.

During the external and internal audits of ISO, EPHARM can use six-sigma procedures to measure and present the current level of the tablet production 
process. Considering, the DPMO, sigma level of production system, yield performance, cost associated with defects, and the deviation of mean value of parameters of tablets from the target value EPHARM can take a measure to solve its problems. These analysis points and other tools of six-sigma can be an input for tackling the root causes of the problems in the company which indirectly fulfill the ISO requirements.

A result is that both approaches get associated and do not compete for resources any longer. Since the goals of the two approaches are the same, there is a greater likelihood of an increase in bottom-line and top-line results on a long-term basis to increase customer satisfaction and employee commitment .Six-Sigma supports ISO and helps EPHARM satisfying the ISO requirements .Further, ISO is an excellent vehicle for documenting and maintaining the process management system involving Six-Sigma. Extensive training is required by both systems for successful deployment.

For this integrated use of six-sigma and ISO, the company should have to give the responsibility to a concerned body to take this assignment in managing the process of combining their ISO requirements with an appropriate Six-sigma tool which can address and solve production problems. Therefore EPHARM could have a possibility of minimizing its overall quality loss and maximize the production performance.

\section{CONCLUSION AND RECOMMENDATIONS}

\section{Conclusions}

- Tablet production section at EPHARM is selected as a DMAIC project to be studied because of the wide variety of products produced in this section, due to its acceptance by the patients and its longer stability in the market. It is also equipped with huge machinery and equipments associated with large number of human resource when compared to the other production sections.

- The control charts prepared for the five tablets production process of EPHARM shows a wide variation in the process. When we see the process variation for all of the parameters in tablet production section, it is difficult to conclude that all the sample batches are produced in the same production process.
- Assay composition, Hardness, Thickness, Diameter and Weight of the tablet which are $50 \%$ of the parameters in the tablet production section are considered in the study for the five major types of tablets which contributes $56.34 \%$ of the tablet production.

- The annual average societal quality loss of the tablet production section of EPHARM is calculated as 14,309,013.96birr per year and also the defect cost associated with the six-sigma analysis is 2,848,360.41 birr/year.

- The tablet production section of EPHARM has a sigma level of 2.514 which indicates $84.48 \%$ of yield performance.

- Maximum 3\% moisture content, $10 \mathrm{rpm}$ mixing speed and 2 minutes mixing time are improved values of the factors which affect the assay composition of drug content in the paracetamol production section and results with a saving of 127,980 birr per year.

- The ISO 9000 certification of EPHARM doesn't show it improves its tablet production process as its societal quality loss increases and tablet quantity loss decreases after the certification which doesn't give a guarantee for consistence production.

\section{Recommendations}

- The management of EPHARM has to be committed to use scientific quality improvement tools in order to reduce the process variations in the production sections and also the workers have to be responsible for their job and keen to participate in any change in the company.

- The DPMO for the tablet production process of EPHARM is calculated as 155,245 with a sigma level of 2.514 and yield $84.487 \%$. As the company produces pharmaceutical products which will be taken through the human's blood, it has to improve its production system sigma level, using the recommended six-sigma tools, near to six-sigma so that the yield will increase to more than $99 \%$ and DPMO will reduce to 3.4 as a final target.

- EPHARM should adjust the machine settings for the mixer speed as $10 \mathrm{rev} / \mathrm{min}$ and mixing time as 2 minutes for the production of paracetamol and also uses a powder with a maximum moisture content of $3 \%$. This will enable the company to improve the process variation in the production area and increase its target value to $95.52 \%$ assay content qualityproducts. In addition EPHARM should take a further study 


\section{International Journal of Engineering Applied Sciences and Technology, 2019 \\ Vol. 4, Issue 4, ISSN No. 2455-2143, Pages 218-225 \\ Published Online August 2019 in IJEAST (http://www.ijeast.com)}

on identifying the root causes and record their measure during the process.

- Epharm should consider further study on some actions like purchasing of new machineries and improving the efficiency of the large volume Parenterals production section which have an effect on the tablet production.

- It is a waste to have a quality management system and process improvement approach existing side-by-side without any integration. It is recommended to align ISO 9000 and sixsigma that help EPHARM to improve the credibility of the ISO 9000 quality management system and the sustainability of the six sigma initiatives at the same time.

\section{ACKNOWLEDGEMENT}

The completion of this study could not have been possible without the active support of Staffs from Wollo University Kombolcha Instutitute of Technology. We would also thank the management of Wollo University Kombolcha Institute of Technology for their keen interest on us at every stage of our research work. Their prompt inspirations, timely suggestions with kindness, enthusiasm and dynamism have enabled us to complete our research. We thank profusely all the staffs of Kombolcha Institute of Technology for their kind help and cooperation throughout our study period.

\section{REFERENCE}

Rakesh, A.,Nonika, B. (2008). "Managing outsourcing process: applying six sigma", Business Process Management Journal, Vol. 14 Iss: 6, pp.829 - 837

Ashish, S., Ravi, S., Kaushal, O. (2010). "Modeling the enablers of Six Sigma using interpreting structural modeling", Journal of Modelling in Management, Vol. 5 Iss: 2, pp.124 - 141

Ton,V., Jos, I., David, P. (2010). "Six Sigma implementation in Ireland: the role of multinational firms", International Journal of Quality \& Reliability Management, Vol. 27 Iss: 9, pp.1054 - 1066

Shirshendu, R., Praveen, C. (2007). "Six Sigma speeds the "settling in" process at Bharati Computers Limited: New employees become productive more quickly after streamlining process", Human Resource Management International Digest, Vol. 15 Iss: 2, pp.39 - 41
Yahia, M. (2011). "Six-Sigma: methodology, tools and its future", Assembly Automation, Vol. 31 Iss: 1 , pp. $79-88$

Pepper,J.,Spedding, A. (2010). "The evolution of lean Six Sigma", International Journal of Quality \& Reliability Management, Vol. 27 Iss: 2, pp.138 155

Narasimhan, K. (2007), "The Six Sigma Performance Handbook: A Statistical Guide to Optimizing", Managing Service Quality, Vol. 17 Iss: 4, pp.486 $-487$

Sean, P. (2004). "Understanding Six Sigma: Implications for Industry and Education", Journal of Industrial Technology, Vol. 20.

Ricardo, B., Charles, T., Tuersley, S. (2006). "Selection of six sigma projects in the UK", The TQM Magazine, Vol. 18 Iss: 5, pp.514 - 527

Tony, B. (2006). "A review and comparison of six sigma and the lean organizations", The TQM Magazine, Vol. 18 Iss: 3, pp.255 - 262.

Jour Bozanic,V (2011), Lean and Six Sigma Concepts-Application in Pharmaceutical Industry, International Journal for Quality Research Vol 5.

Azmery K (2013), Six Sigma in Pharmaceutical Manufacturing Industry, Published in Pharmaceutical Articles. 